\title{
The effect of printing velocity on the temperature and viscosity of the polymer thread at the nozzle exit in 3D printers
}

\author{
Alberto Baeza-Campuzano ${ }^{1)}$ (ORCID ID: 0000-0002-7241-6836), Victor M. Castaño ${ }^{1), ~ *)}$ (0000-0002-2983-5293) \\ DOI: dx.doi.org/10.14314/polimery.2021.2.6
}

\begin{abstract}
Fused Deposition Modelling (FDM) is a powerful method for advanced additive manufacturing of polymeric materials, due to its simplicity and low cost. However, the process implies complex phenomena which are not fully understood yet. In particular, the effect of viscosity on the printed thread is a key parameter to control if good quality products are to be obtained. Experimental data of two grades of acrylonitrile-butadiene- styrene copolymer (ABS) was employed to analyse, by using ANSYS Fluent simulation package, six printing velocities at a temperature of $230^{\circ} \mathrm{C}$. A drastic temperature change was observed as the printing velocity increases, confirming the effect of viscosity on the shear created on the wall of the nozzle transversal to the printing bed. The polymers analysed present different viscosity behavior even under the same angular frequency range (0.1 to $100 \mathrm{rad} / \mathrm{s})$, and testing temperature $\left(230^{\circ} \mathrm{C}\right)$, which could lead to inhomogeneities. Our results allow taking into account these parameters as part of the design criteria.
\end{abstract}

Keywords: Fused Deposition Modelling, 3D printing, additive manufacturing, ANSYS modelling.

\section{Wpływ prędkości drukowania na temperaturę i lepkość nici polimerowej na wyjściu z dyszy drukarki 3D}

Streszczenie: Technologia druku 3D - FDM (Fused Deposition Modelling), dzięki prostocie i niskiemu kosztowi, stanowi skuteczną zaawansowaną metodę przyrostowego wytwarzania elementów $\mathrm{z}$ materiałów polimerowych. Jednak występujące $\mathrm{w}$ tym procesie złożone zjawiska nie są jeszcze w pełni poznane. Kluczowym parametrem determinującym możliwość uzyskania produktów dobrej jakości jest lepkość stopionego polimeru, zależna od prędkości druku. Na podstawie wyników badań dwóch odmian kopolimeru akrylonitryl-butadien-styren (ABS), za pomocą programu symulacyjnego ANSYS Fluent, przeanalizowano zależności dla sześciu prędkości drukowania w temperaturze $230^{\circ} \mathrm{C}$. Zaobserwowano istotną zmianę temperatury polimerowej nici wraz ze wzrostem prędkości druku, co potwierdza wpływ lepkości na naprężenia ścinające występujące na ściance dyszy, poprzecznie do stołu drukującego. Analizowane polimery wykazywały różną lepkość, nawet $\mathrm{w}$ tym samym zakresie częstotliwości kątowej $(0,1$ do $100 \mathrm{rad} / \mathrm{s})$ i w takiej samej temperaturze $\left(230^{\circ} \mathrm{C}\right)$, co może prowadzić do niejednorodności stopionego tworzywa. Uzyskane wyniki wskazują, że parametry te należy uwzględnić przy projektowaniu procesu druku.

Słowa kluczowe: metoda Fused Deposition Modelling, druk 3D, wytwarzanie addytywne, modelowanie ANSYS.

Fused Deposition Modelling (FDM) is a technique that can achieve today's consumer requirements of high quality and reasonable priced manufactured products [1]. FDM allows simple prototyping in diverse areas such as food engineering, aerospace engineering, and mechanical engineering [2]. Generally speaking, FDM can be defined as

\footnotetext{
1) Universidad Nacional Autónoma de México, Centro de Física Aplicada y Tecnología Avanzada, Boulevard Juriquilla 3001, Querétaro 76230.

*) Author for correspondence: vmcastano@unam.mx
}

the process of joining materials to build objects from three dimensional (3D) model data, layer by layer, as opposed to standard subtractive manufacturing technology [1].

The main components of a typical FDM system are: gears and feeding motor, polytetrafluoroethylene (PTFE), teflon tube, heat sink, cooling fan, heat break, heat block and nozzle. The gears and feeding motor lead the filament $(1.75 \mathrm{~mm}$ in diameter) to produce a polymer flow at a controlled velocity. The force applied by the gears against the filament is enough as to create motion. The PTFE tube guides the filament from the motor to the 


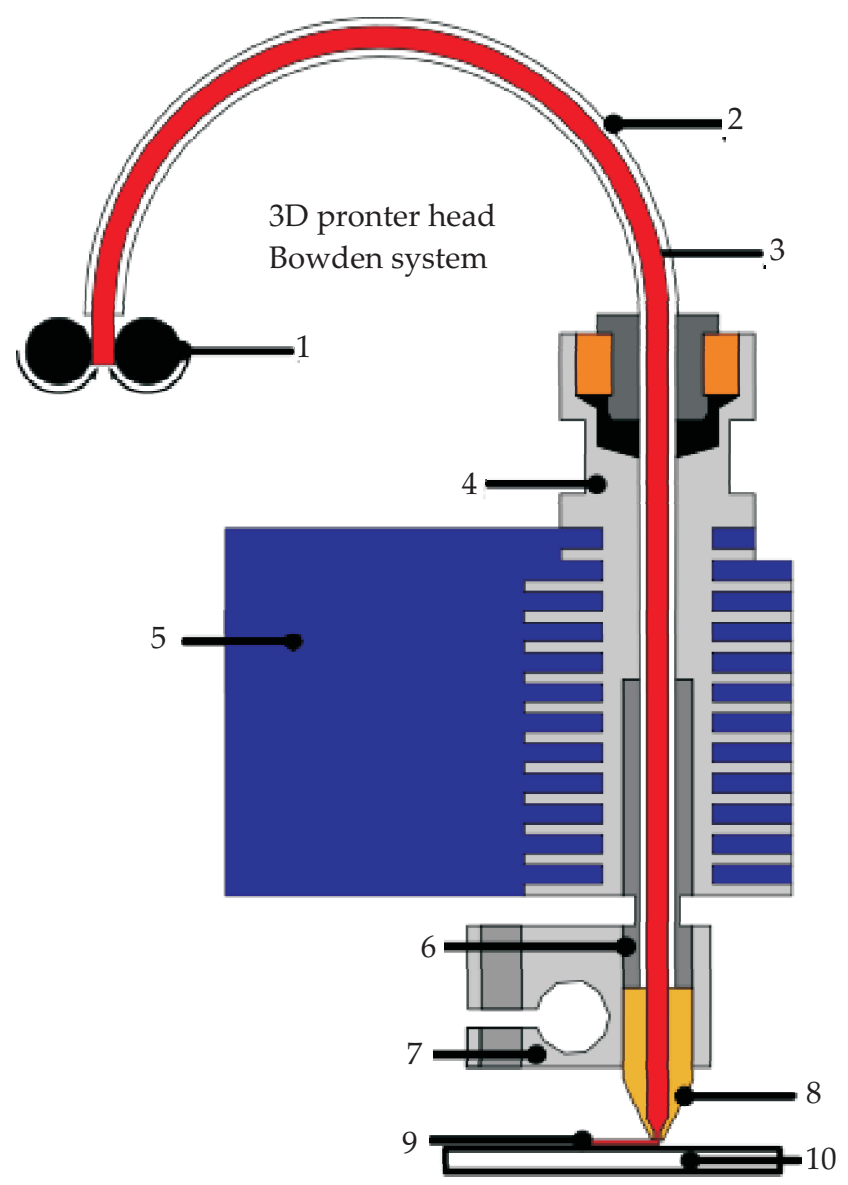

Fig. 1.3D printer head, Bowden system: 1 - feeding motor, gears and bearing compressing the filament, 2 - PTFE (teflon) tube guiding the polymer filament, 3 - polymer filament $1.75 \mathrm{~mm}, 4$ heat sink, 5 - cooling fan, 6 - heat break, 7 - heat block, 8 - nozzle, 9 - thread (molten polymer) coming out, 10 - printing bed

entrance of the heat sink, which receives cooled air by the fan, protecting it from the high temperatures produced by the heat block and the heat break. The polymer filament is guided and melted, to allow the nozzle to create $0.4 \mathrm{~mm}$ threads with a contraction at a $60^{\circ}$ angle. Figure 1 shows schematically a typical layout of a FDM system.

Despite that the different 3D printers have unique characteristics, the diagram of Fig. 1 represents the most common commercial systems.

The filament flows at a given velocity as the printer head moves. When the filament reaches the hot zone (heat break and nozzle), the melting process begins, and the nozzle creates the $0.4 \mathrm{~mm}$ thread. As the material exits the nozzle, it gets in contact with the environment temperature and the printing bed, thus beginning the cooling process.

Many parameters and rheological properties might affect the mechanical properties and performance of both the 3D printer and the final printed parts. For example, the temperature of the heated block and nozzle has a great effect on the performance of the printer, because of the viscosities involved. The combination of the operating parameters of the 3D printer with the rheological properties of the material itself becomes a difficult task, which can be aided through mathematical modelling. There are several articles in the literature explaining how the $3 \mathrm{D}$ printing system works, the most common problems that are found and how to solve them [3, 4].

The mechanical properties of the printed thread coming out of the nozzle depend on the temperature and velocity inside the nozzle tip and on the printing velocity, which creates a shear effect. A model to design a desire surface finish has been proposed [5, 6], with a good agreement with the final printed part, thickness of the layer and deposition path. Some systems for changing the printing orientation have been applied to improve the finish and the mechanical properties [7]. Other model was proposed to take into account the non-linear behavior of the temperature in the system, however, the model only applies to selective laser sintering [8]. FDM technology has been studied in terms of parameters such as the orientation of the thread and how the mechanical properties of the final product change when the parameters of the printer change and it has been found that the gap or slice thickness is extremely relevant [9]. Experimental measurements of the thermal expansion, depending on the way a product is printed, have demonstrated the effect of layer orientation and thickness [10]. The thread surface has also been studied in terms of its geometry and the isothermal effect on the thread [1]. Neck growing of the thread depends on different parameters [11] and a full three dimensional thermal model describing the nonlinearity effect of the deposition, was developed by ANSYS finite element method [12].

Also, mathematical analysis has been used to obtain the melt front location by considering that the liquid is governed by a two dimensional axisymmetric steadystate advection-conduction equation [13].

The simulation package ANSYS has been used to simulate the polymer flow within the nozzle, by considering isothermal conditions [14]. The calculation of the pressure drop when the contraction angle at the nozzle is changed, was carried out considering an isothermal process, as well $[15,16]$. There is a mathematical analysis which considers the shape of the nozzle, which leads to different exit temperatures and velocity flows of the printing thread [17]. Also, thermal effects limit the attainable extrusion velocity, since the maximum heat flow between the filament and the wall may not be high enough as to fully heat the filament to the required temperature at the nozzle tip [18]. This causes the thread at the nozzle exit to suffer high temperature variations, which in turn affects the homogeneity of the final product [19].

In spite of all the attention that FDM is drawing among the specialists, to our knowledge there is scarce research that analyses in detail the shear velocity applied between the printer head and the printing bed. Accordingly, the aim of this paper is to show how the viscosity of different polymer grades has an impact on the behavior of the temperature and velocity of the thread when it exits the nozzle. Also, we show how the effect of the shear applied by the transversal nozzle tip wall against the printing bed, is related to the viscosity. 


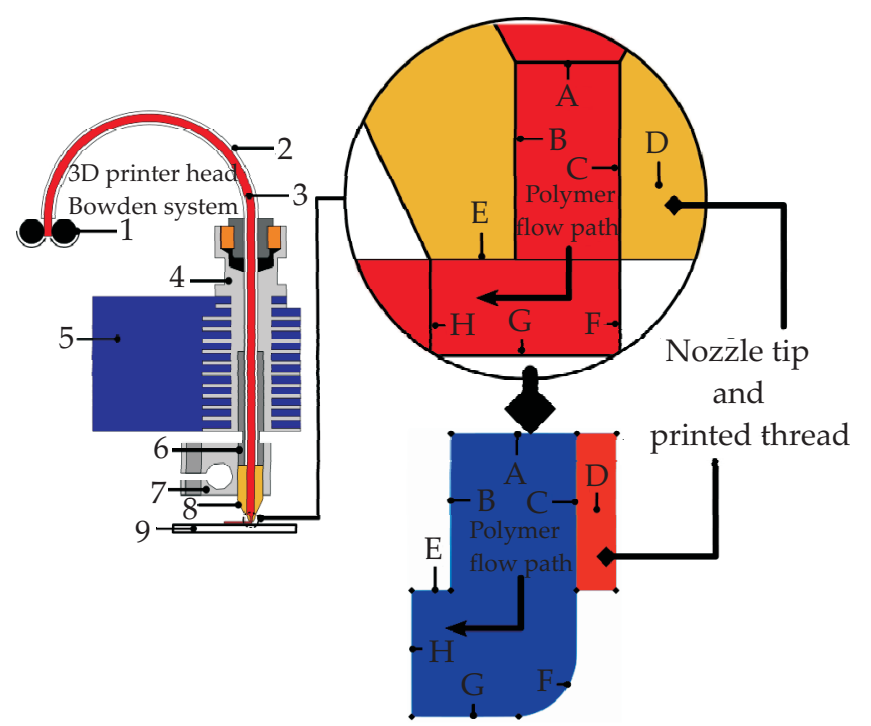

Fig. 2. Nozzle tip and thread coming out of the nozzle (system applied into Fluent): A - nozzle tip entrance, B - nozzle tip left wall, C - nozzle tip right wall, D - nozzle tip, E - nozzle shearing wall against the printing bed, $\mathrm{F}$ - right free surface of the thread coming out of the nozzle, G - printing bed, $\mathrm{H}$ - left free surface of the thread

In other words, temperature, shearing effect, and velocity are analysed while the thread stills in contact with some part of the nozzle. The analysis was carried out by considering the geometry of the nozzle tip and the thread schematically depicted in Fig. 2.

\section{EXPERIMENTAL PART}

\section{Materials}

Two grades of ABS copolymer (3D printing filament) with different viscosities were used. The first one is obtained from the author Ajinjeru [20] (named LUSTRAN 433, it was obtained from Techmer ES). The second we received from Mackay [21] (the polymer manufacturer was Village plastics).

For Ajinjeru's polymer the samples were in pellet after dried at $85^{\circ} \mathrm{C}$ for 4 hours, prior to testing, after the pellets were used in the rheometer, the filament polymer was used in the printer. For Mackay's polymer the material was used as received, and no further actions were applied.

\section{Methodology}

\section{Rheology}

The rheology was tackled as follows: Ajinjeru measured with a rheometer of parallel plate of $25 \mathrm{~mm}$ and frequency range of $0.1-628 \mathrm{rad} / \mathrm{s}$, within linear viscoelastic regime and temperatures of 230,250 and $270^{\circ} \mathrm{C}$. Mackay used $8 \mathrm{~mm}$ parallel plates, carried out within the linear viscoelastic regime and frequency sweep range from 100 to $0.01 \mathrm{rad} / \mathrm{s}$ and temperatures of 210 to 250 every $10^{\circ} \mathrm{C}$. The two authors used $230^{\circ} \mathrm{C}$ for processing temperature $[20,21]$. We used power law model to fit the data in all three polymer, this can be seen in next sections.

\section{Chosen velocities}

Feeding velocity and printing velocity were used to perform the simulation, the feeding velocity is intrinsically obtained while setting the printing velocity, see Eq. 1 [22]

$$
\frac{V_{x}}{V_{a}}=\left(\frac{D}{d^{\prime}}\right)^{2}
$$

where: $d^{\prime}$ - the thread diameter $(0.4 \mathrm{~mm}), D$ - the filament diameter $(1.75 \mathrm{~mm}), V_{a}$ - printing velocity, $V_{x}$-feeding velocity. Equation 1 fits most of the commercial used printers. The printing velocities proposed are $5 \mathrm{~mm} / \mathrm{s}$ as a lower extreme, knowing this is rarely used. It was followed by 20, 30, 40, 60 and $80 \mathrm{~mm} / \mathrm{s}$, because they are the most common and used printing velocities. This can be seen in Table 1.

T a b l e 1. Velocities applied into the simulation

\begin{tabular}{c|c|c|c}
\hline $\begin{array}{c}\text { Velocity } \\
\text { name }\end{array}$ & $\begin{array}{c}\text { Printing } \\
\text { velocity } \\
\mathrm{m} / \mathrm{s}\end{array}$ & $\begin{array}{c}\text { Feeding } \\
\text { velocity } \\
\mathrm{m} / \mathrm{s}\end{array}$ & $\begin{array}{c}\text { Reason of } \\
\text { chosen } \\
\text { velocity }\end{array}$ \\
\hline Vel 1 & 0.005 & 0.00026 & $\begin{array}{c}\text { Stating } \\
\text { velocity }\end{array}$ \\
\hline Vel 2 & 0.02 & 0.00104 & \\
Vel 3 & 0.03 & 0.00157 & $\begin{array}{c}\text { Relevant and } \\
\text { most used } \\
\text { vel 4 }\end{array}$ \\
Vel 5 & 0.04 & 0.00209 & \\
Vel 6 & 0.06 & 0.00313 & \\
\hline
\end{tabular}

\section{Positions for temperatures and velocities measurement}

The temperature and velocity filed were obtained at three different relevant positions within in the system: 1 nozzle outlet 1, 2 thread outlet transversal 2, 3 thread outlet transversal 3 . The second and third position is when the polymer enters in contact with the printing bed and environment temperature. This can be seen in Fig. 3 .

\section{Governing equations, and boundary conditions}

In order to obtain the temperature field of the polymer at different velocities and different position, we need a set of governing equation, assumptions and boundary conditions. Therefore, the conservation of mass, conservation of momentum and conservation of energy, are considered for the analysis. However, this case takes into the account the changes of viscosity which in turns depends on temperature and shear rate. Hence, power law along with Arrhenius model are considered as well.

The mass conservation equation is given by Eq. 2 . 


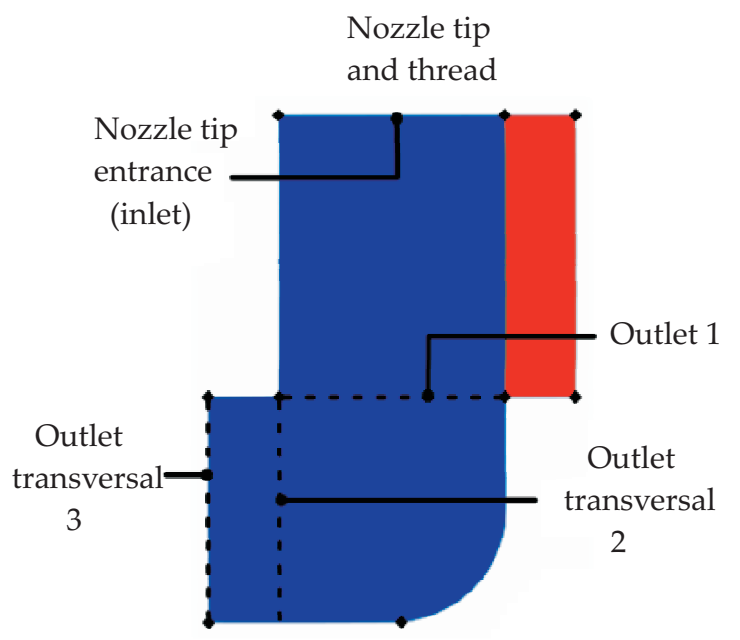

Fig. 3. Outlet 1 - from tip entrance until outlet 1 the material stills inside the nozzle, Outlet transversal 2 - before the material is sheared by the nozzle, the thread faces the environment temperature, Outlet transversal 3 - the material is sheared by the nozzle, the thread faces the environment temperature

$$
\frac{\delta u}{\delta x}+\frac{\delta v}{\delta y}=0
$$

The first term is due to stretching in the ' $x$ ' direction and the second term is due stretching in the second direction (this is written in ' $x$ ' and ' $y$ ' coordinates but some other case might need ' $x$ ' and ' $r$ '- radial direction for polar coordinates). The equation of momentum conservation is shown in Eq. 3.

$$
\varrho\left(\begin{array}{l}
\left.u \frac{\delta u}{\delta x}+v \frac{\delta u}{\delta y}\right)=-\frac{\delta \varrho}{\delta x}+\eta \nabla^{2} u \\
\varrho\left(u \frac{\delta v}{\delta x}+v \frac{\delta v}{\delta y}\right)=-\frac{\delta \varrho}{\delta y}+\eta \nabla^{2} v
\end{array}\right.
$$

Equation 3, where the first line is the momentum conservation in the ' $x$ ' direction and the terms in the right side represents the force in the ' $x$ ' direction for infinitesimal fluid particle. On the left side, the mass times acceleration is shown, the term $v$ multiplied by $\delta u / \delta y$ represent the acceleration in the ' $x$ ' direction due to particle motion in ' $y$ ' direction assuming, steady flow and constant flow. $\eta$ represents the viscosity, it is obtained with power law fluid and the Arrhenius model. This can be observed in Eq. 4.

$$
\begin{gathered}
\eta=K \dot{\gamma}^{n-1}[H(T)] \\
H(T)=\exp \left[\alpha\left(\frac{1}{T-T_{0}}-\frac{1}{T_{\alpha}-T_{0}}\right)\right]
\end{gathered}
$$

Equation 4 show the viscosity as a temperature dependant where $\alpha$ is the activation energy and $T_{\alpha}$ is a reference temperature for which $H(T)=1$. $T_{0}$ which is the temperature shift, is set to 0 by default, and corresponds to the lowest temperature that is thermodynamically acceptable. Therefore, $T_{\alpha}$ and $T_{0}$ are absolute temper- atures. Temperature dependence is only included when the energy equation is enabled.

We have to notice in Eq. 4 that viscosity depends on the shear rate $\dot{\gamma}$ as well. $K$ is the consistency index, $n$ is a fitting parameter.

As was mentioned before if the material depends on temperature and the Arrhenius equations is presented, energy equation must be activated as well.

$$
\begin{aligned}
\frac{\delta}{\delta t}(\varrho E)+\nabla \cdot[\vec{v}(\varrho E+\varrho)] & =\nabla \cdot\left[k_{\text {eff }} \nabla T-\sum_{j} h_{j} \vec{j}+\left(\bar{\tau}_{\text {eff }} \cdot \vec{v}\right)\right]+S_{h} \\
E & =h-\frac{p}{\varrho}+\frac{v^{2}}{2}
\end{aligned}
$$

In Eq. $5 k_{\text {eff }}$ is the effective conductivity, on the left side of the equation the convection term is present and the right hand side shows, the energy transfer due to conduction, species diffusion and viscous dissipation respectively. The term $S_{h}$ is heat due to chemical reaction which in this case is neglected. For energy we have $h$ that represents enthalpy, $p$ pressure and $\varrho$ density. Must be consider that Eq. 5 is entirely solved by ANSYS Fluent also the input data is shown next.

Those equations were carried out with following boundary conditions: at the entrance we have the inlet flow, the temperature applied on the block is the same as applying directly on the heat break and nozzle, zero velocity at the wall, viscous heating considered, the components of the system are in perfect contact each other.

\section{Input parameters and material data}

ABS Ajinjeru's: density o $1150 \mathrm{~kg} / \mathrm{m}^{3}$ (constant), specific heat $C_{p} 2100 \mathrm{~J} /(\mathrm{kg} \cdot \mathrm{C})$ (constant), thermal conductivity $k$ $0.21 \mathrm{~W} /(\mathrm{m} \cdot \mathrm{C})$ (constant), viscosity non Newtonian power law fluid Eq. 4 and Table 2 (for data), activation energy $\alpha$ 3044.912, for Arrhenius Eq. 4, considering shear rate and temperature dependent behavior.

T a b l e 2. Fitting values of the power law model on the two types of polymers

\begin{tabular}{c|c|c}
\hline Polymer & $K$ & $n$ \\
\hline ABS Ajinjeru & 6574.95 & 0.513 \\
ABS Mackay & 10239.70 & 0.504 \\
\hline
\end{tabular}

ABS Mackay's: density @ $1150 \mathrm{~kg} / \mathrm{m}^{3}$ (constant), specific heat $C_{p} 2100 \mathrm{~J} /(\mathrm{kg} \cdot \mathrm{C})$ (constant), thermal conductivity $k$ $0.21 \mathrm{~W} /(\mathrm{m} \cdot \mathrm{C})($ constant), viscosity non Newtonian power law fluid Eq. 4 and Table 2 (for data), activation energy $\alpha$ 2168.214, for Arrhenius Eq. 4, considering shear rate and temperature dependent behavior.

Brass data: density o $8730 \mathrm{~kg} / \mathrm{m}^{3}$ (constant), specific heat $C_{p} 380 \mathrm{~J} /(\mathrm{kg} \cdot \mathrm{C})$ (constant), thermal conductivity $k$ $\mathrm{W} /(\mathrm{m} \cdot \mathrm{C})$ (constant).

Temperatures and velocities: printing velocity, Table 1 , velocity applied in the shearing wall, feeding velocity 


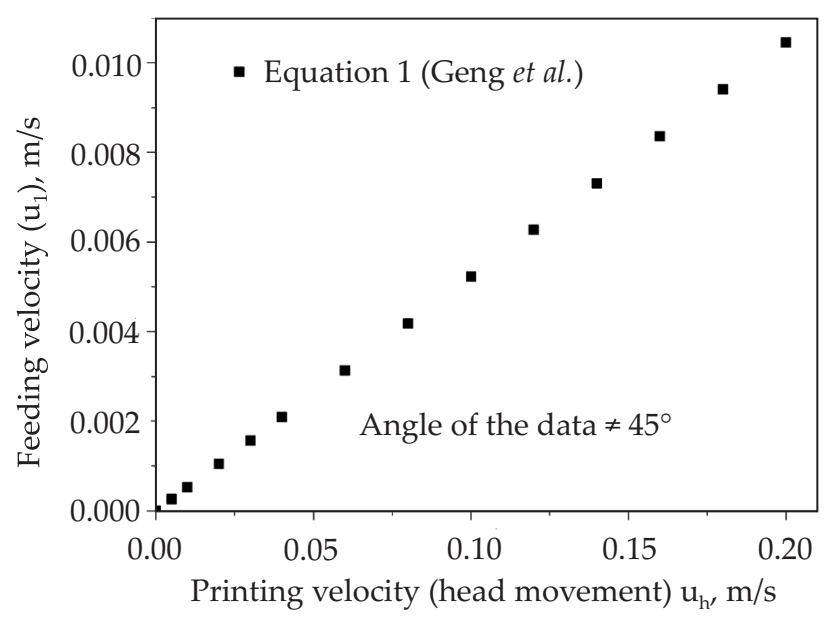

Fig. 4. Feeding velocity obtained from Eq. 1; the data does not present $45^{\circ}$ angle

Table 1, wall temperature, $230^{\circ} \mathrm{C}$ (constant through all the wall), temperature of the printing bed $70^{\circ} \mathrm{C}$, environment temperature $25^{\circ} \mathrm{C}$.

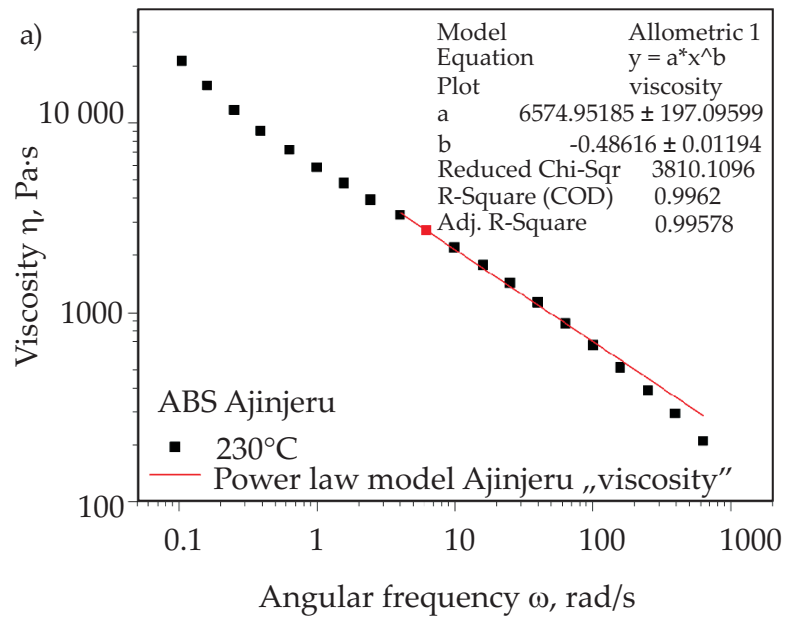

The system was fully analysed with 1500 iteration which took around 2 hours and a half.

\section{RESULTS AND DISCUSSION}

The velocity applied into the simulation was calculated with Eq. 1. Figure 4 shows how the feeding velocity is obtained.

The curve presents dependence for the most common, used and commercial 3D printer. According to the curve, if the printing curve increases the feeding velocity linearly increases as well. However, in the real case scenario all feeding and printing motors have a threshold. What does it mean? At certain point the graph will not present linearity anymore, because the motor will reach its threshold.

The viscosity was model with the power law function (Eq. 4), the two types of ABS have different viscosities, this can be seen in Fig. 5 .

Figure 5 shows the power law model applied onto the graphs the fitting parameters can be seen in Table 2.

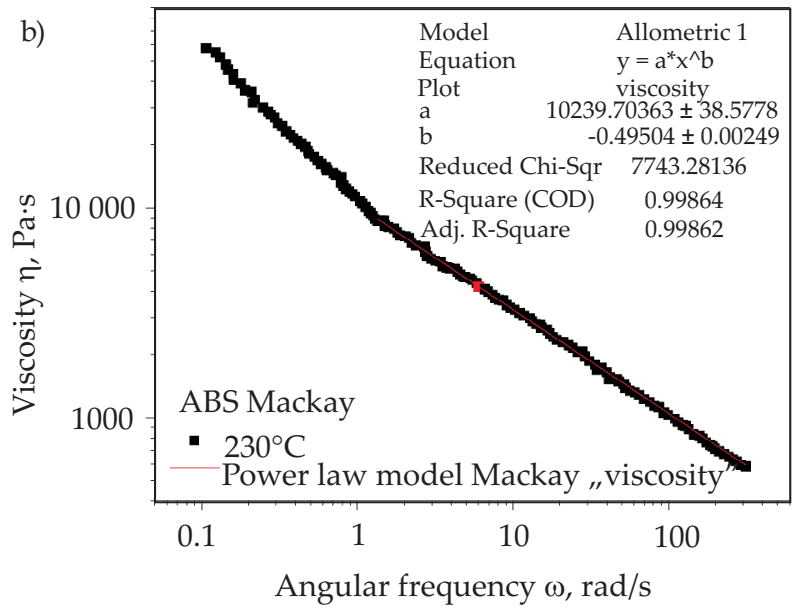

Fig. 5. Viscosity curves along with the power law model: a) ABS from Ajinjeru, b) ABS from Mackay
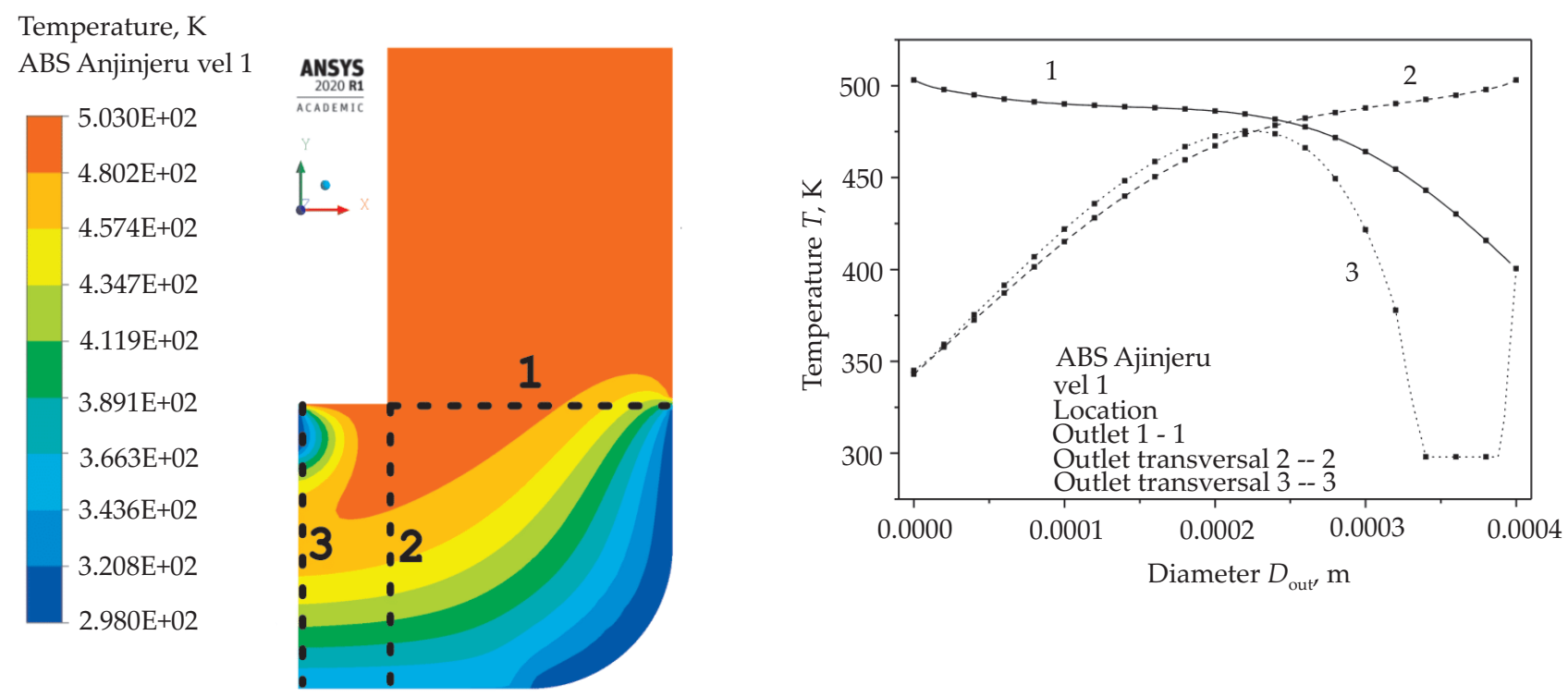

Fig. 6. Shows how the graph represents the temperature behavior on each location within the system: 1 - outlet 1,2-outlet transversal 2, 3 - outlet transversal $3[20,21]$ 


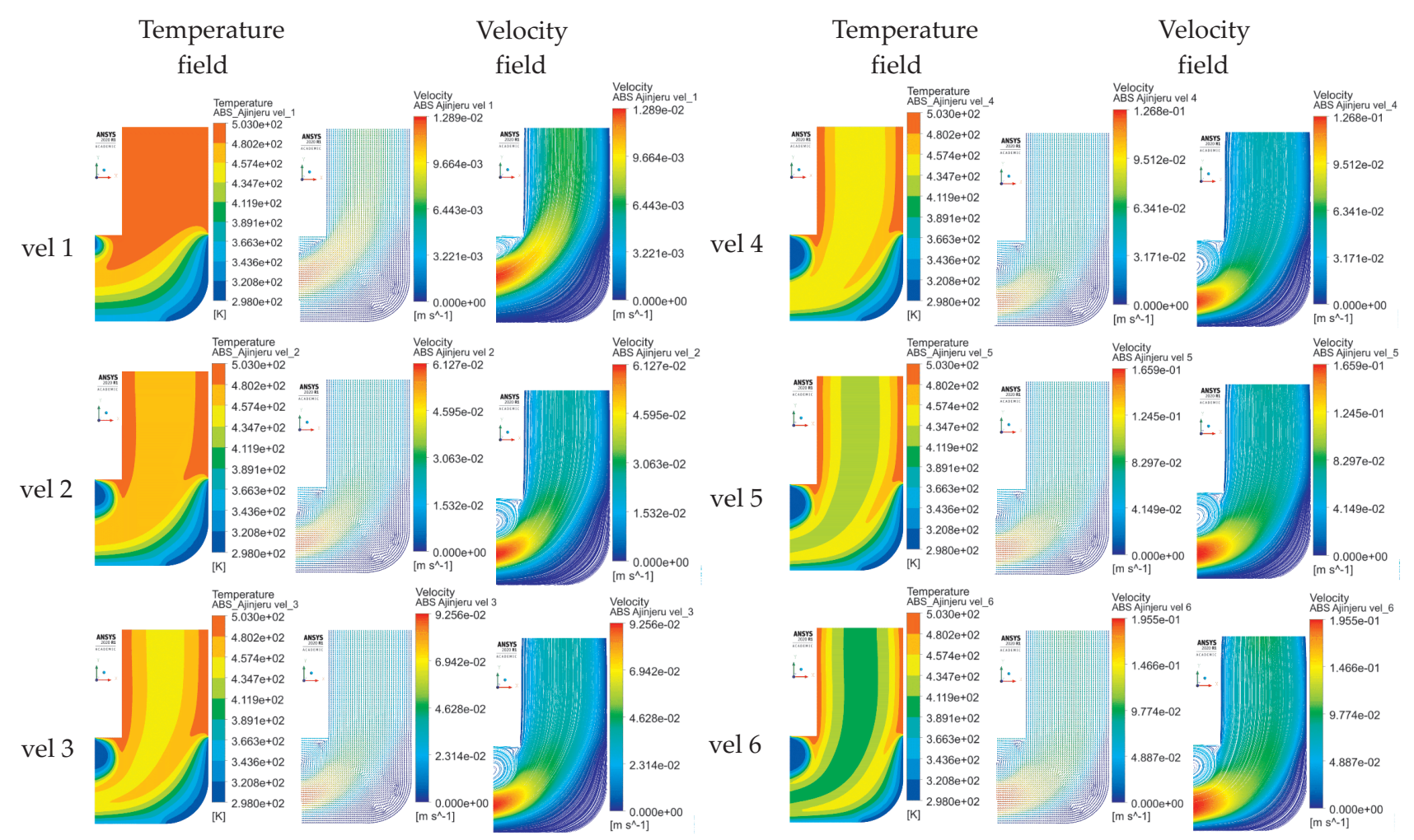

Fig. 7. Results of temperature and velocities fields after simulations, using the velocities previously proposed in Table 1; ABS from Ajinjeru

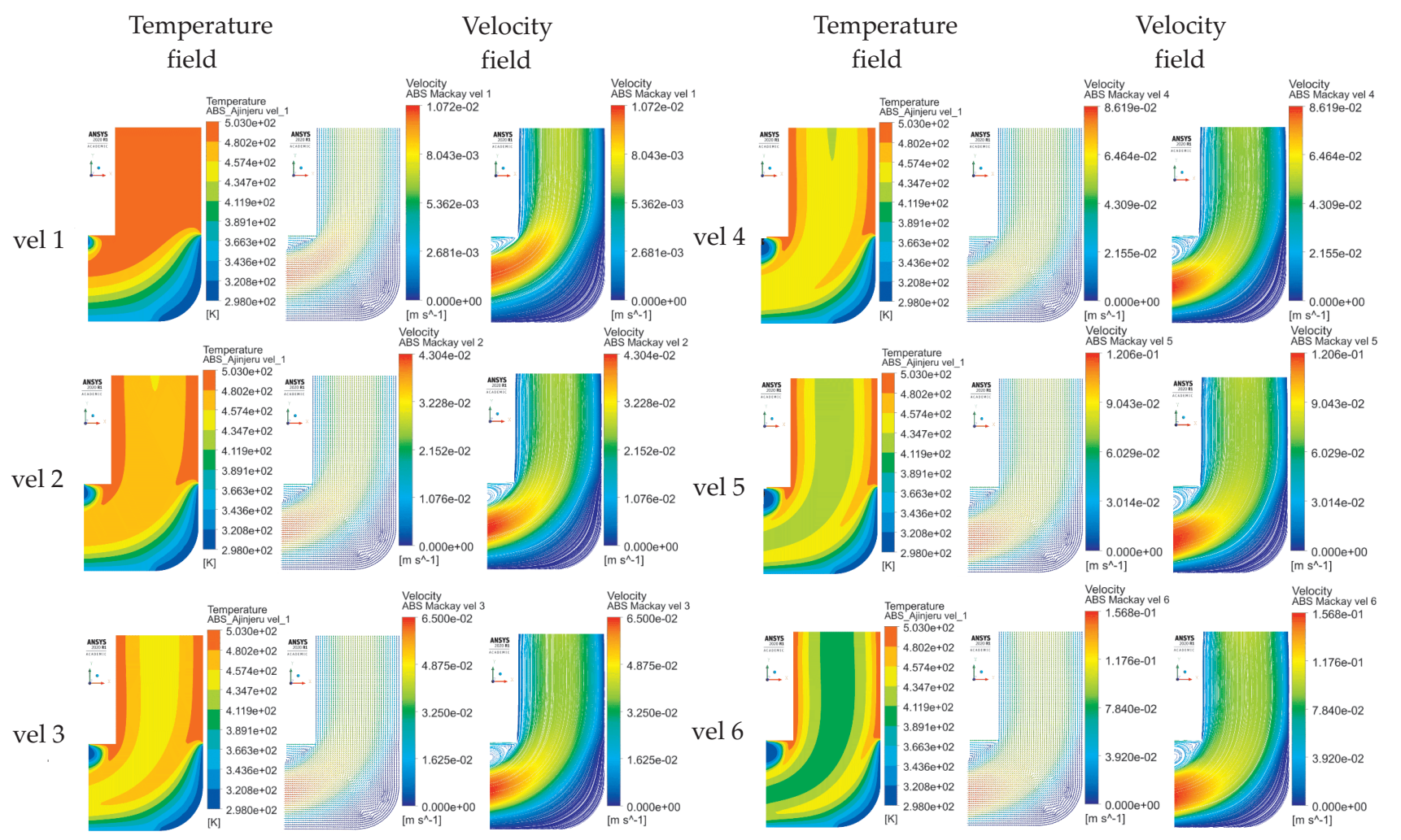

Fig. 8. Results of temperature and velocities fields after simulations, using the velocities previously proposed in Table 1, ABS Mackay

As was mentioned before the simulations were carried out in ANSYS Fluent, academic version. The locations previously explained in Fig. 3 are represented in a graph shape, see Fig. 6.
The results from the simulations applying $230^{\circ} \mathrm{C}$ and the six different velocities previously mentioned in Table 1, can be seen next (see Figs. 7 and 8). 
Figures 7 and 8 show the temperature comparison between two types of polymers, can be observed that ABS from Mackay's shows the colder zones compared to ABS from Ajinjerus's. Considering the first velocity of both polymers, is possible to observe how colder zones are presented in Mackay's compared to Ajinjerus's polymer. Looking at the top left corner of velocity one, there is a blue zone presenting low temperatures in Mackay's and Ajinjeru's polymer, with the difference that such blue zone is lower in Mackay's than Ajinjeru's. In the case of the velocities, stagnation with vortices are presented at the same location (top left of velocity figure), the vortices in Ajinjeru's are higher than Mackay's. Therefore, while the printing velocity increases in both polymers, the difference in temperature is more pronounced, like in vortices as well. This behavior has a reason, looking back at Fig. 5 is possible to observe the viscosity from Mackay's polymer is higher than Ajinjeru's at low and higher frequencies. Hence, this arises the next three points:

- The temperature presented in Ajinjeru's polymer presented higher hotter zones than Mackay's, because of the viscosity. In others words the material with high viscosity heat slower than the same material with lower viscosities.

- The velocity presented shows higher vortices in Ajinjeru's than Mackay's polymer. It has a strong relation to the viscosity, because Mackay's presents higher viscosity than Ajinjeru's. In other words, materials with higher viscosities present more resistance to motion compared to the same material with low viscosities.

- The vortices are well pronounced in both cases, and the printing velocity has a strong influence in all velocities and both polymers. Why the printing velocity have an impact in vortices?, the answer is because the material is sheared between the nozzle and the printing bed, when the printing velocity increases the feeding velocity increases and the shearing effect increases as well. Looking at both polymers is harder to shear polymers with higher viscosities than lowers.

Is possible to observe in Figs. 7 and 8 how the temperature decreases considerably while the feeding velocity increases. When the velocity is in the lowest extreme the temperature fully melts the material and the environment temperature does not present the big effects, this
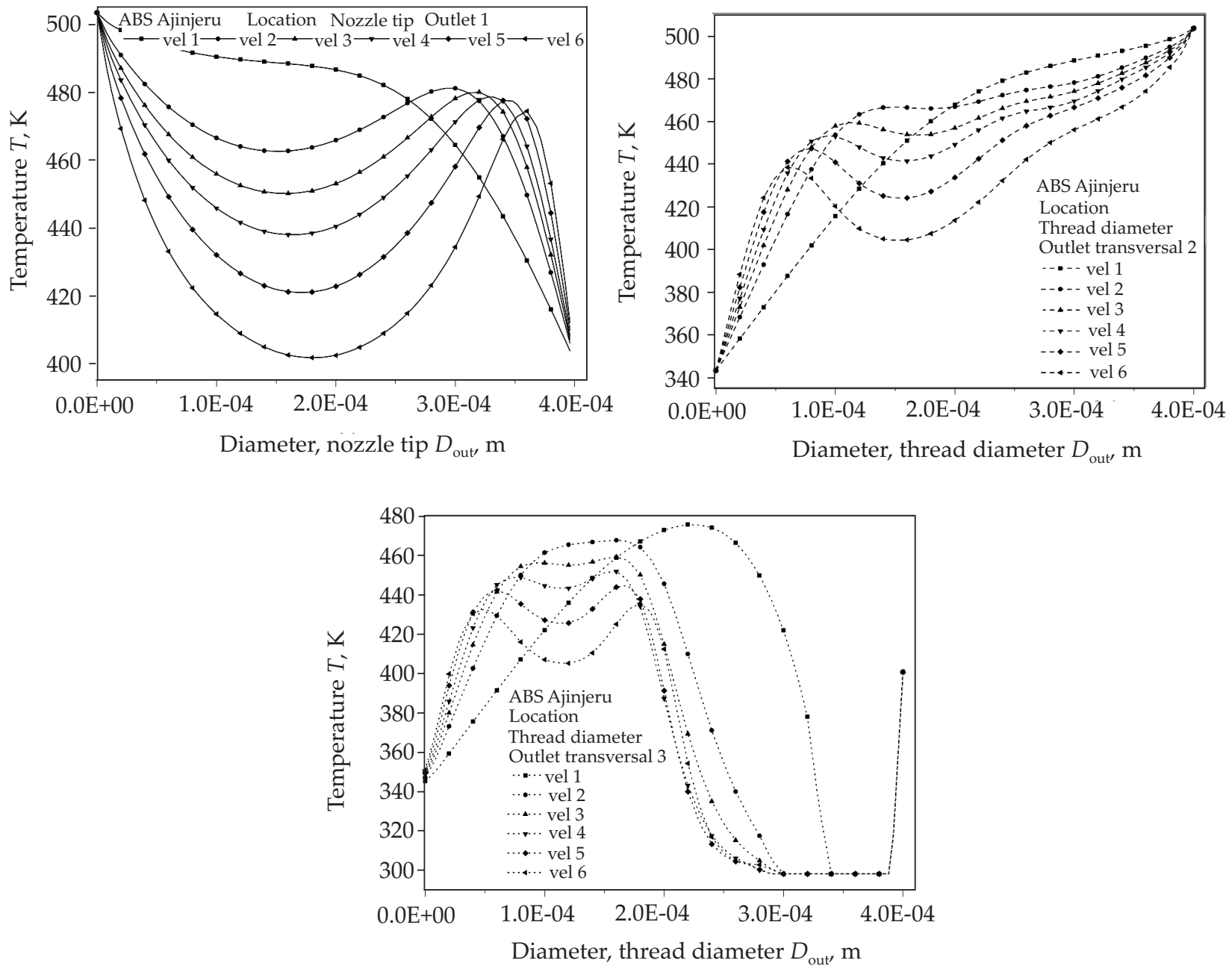

Fig. 9. Temperature at 3 positions: a) outlet 1, b) outlet transversal 2, c) outlet transversal 3, from 6 different velocities; ABS Ajinjeru 

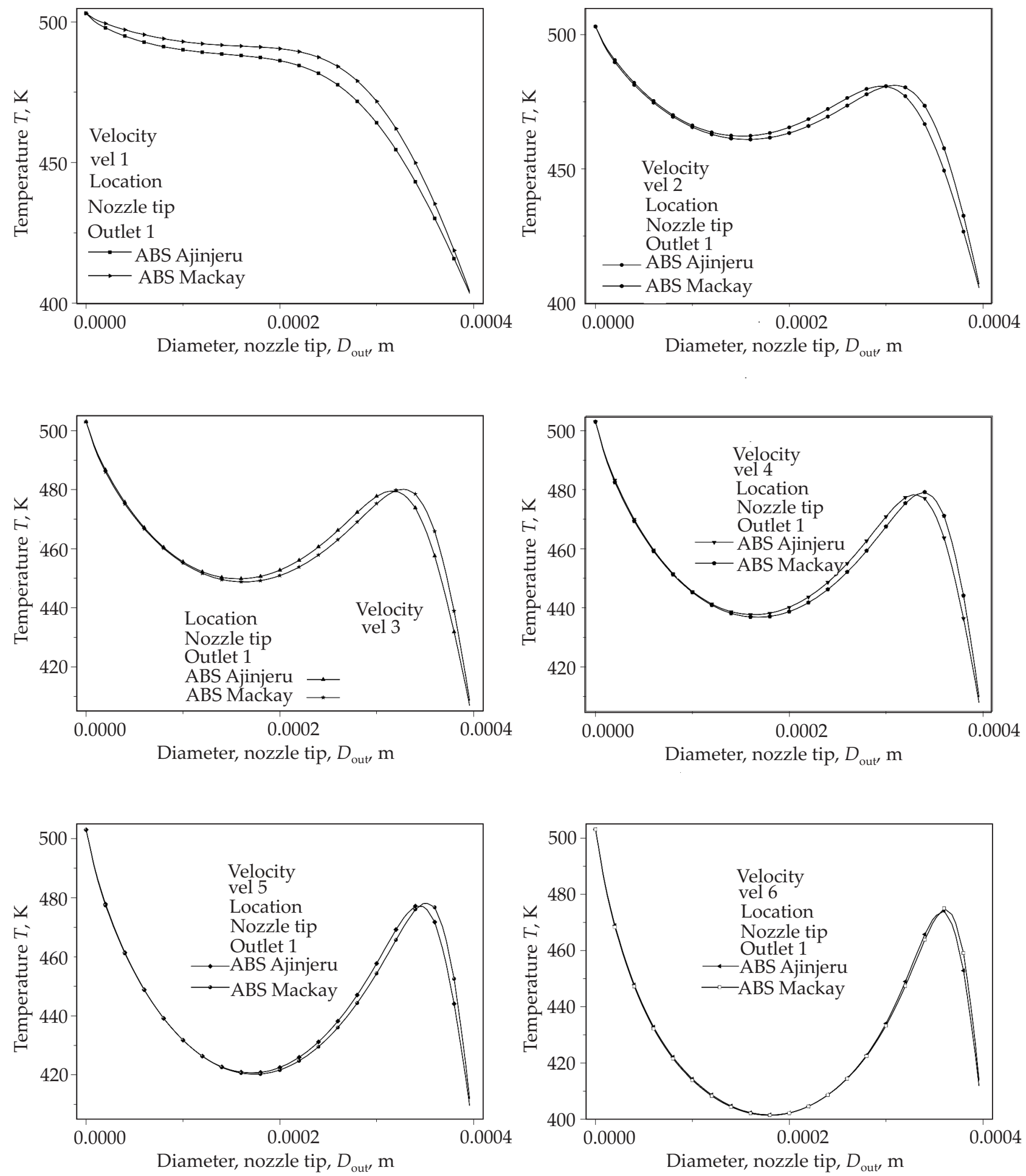

Fig. 10. Temperature of the thread at the outlet 1 changing the six printing velocities previously proposed, considering both polymers

behavior of gradually reducing the fully molten material is a consequence of the viscosity behavior (power law model), the polymer did not presented any zero shear viscosity (plateau). The shear left wall, also presents great impact in the temperature, because closer the material to the wall higher thickness of molten material is present.

The velocity flow is another great effect that can be seen in Figs. 7 and 8, as was mentioned before, the feeding velocity is obtained when the printing velocity is applied, therefore when the printing velocity increases the feeding velocity increases as well. Hence, is possible to see the velocity field in Figs. 7 and 8. Vortices are present, they increase considerably while the printing velocity increases. However, this behavior is more pronounced in ABS from Ajinjeru because the viscosity is lower compared to the viscosity from Mackay's polymer.

The vortices occur because, there is clash of velocities, from the feeding one (going down for the polymer flow), 

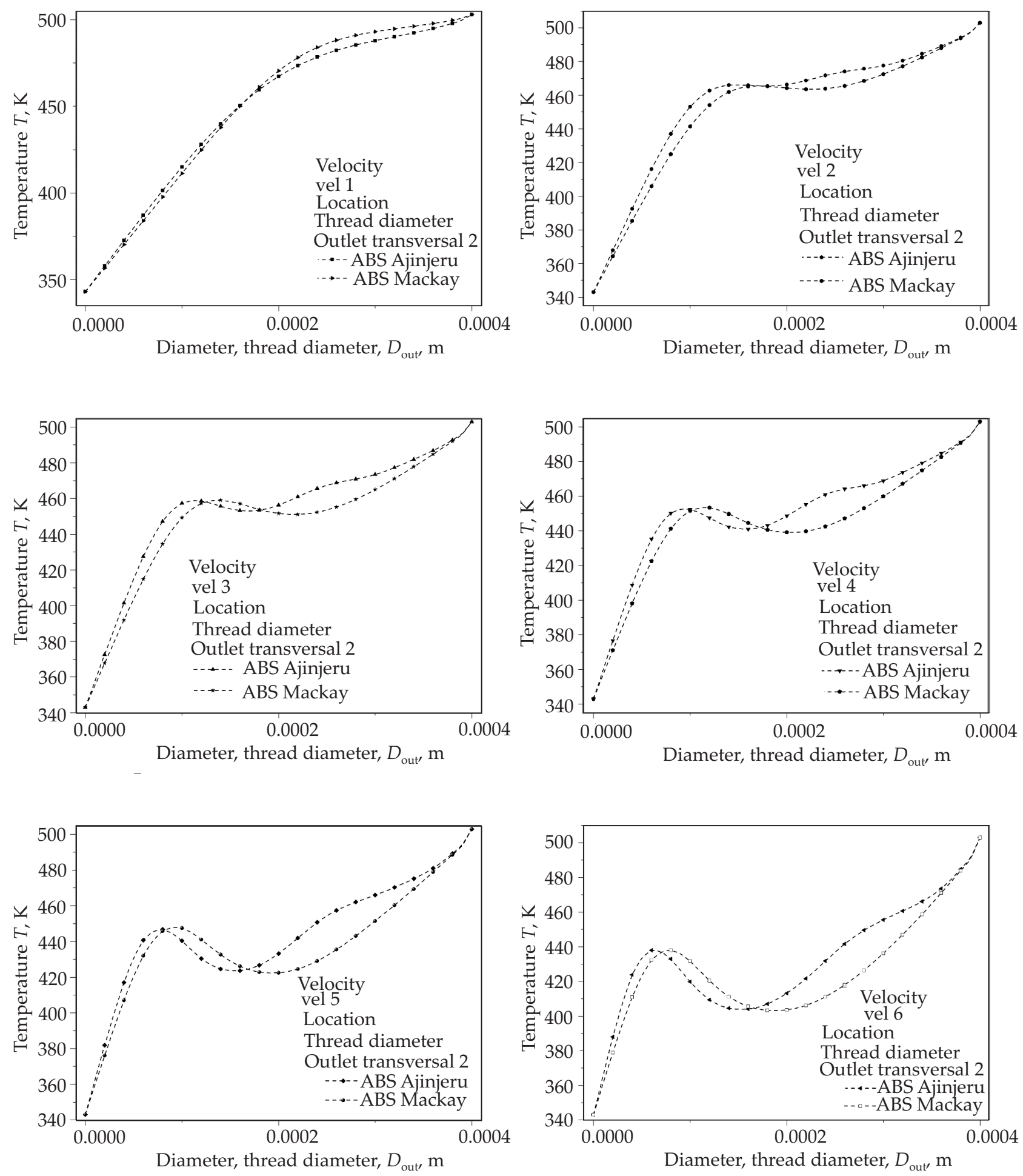

Fig. 11. Temperature behavior at different locations

and the printing one (applied onto left shearing wall). Also, is possible to observe that velocity 1 present the vortices with low size and there is not stagnation point, but while the velocity increases the vortices increases considerably and a possible stagnation point might be present. Finally, we can see that, after velocity 4 the vortices do not change but the possible stagnation point is lowered considerably.

Temperature behavior from 6 velocities and the 3 mentioned positions is shown in Fig. 9.
Figure 9 shows the temperature results, basically how it changes when the feeding velocity and printing velocity are increased, in outlet 1 position, we observed that temperature decreases while the velocity goes up. However, position outlet transversal 2 and 3 the temperature increases while the velocity goes up but after $0.0005 \mathrm{~m}$ diameter the temperature decreases considerably. This might happen because of the shearing velocity and the vortices explained previously, also must be consider that 

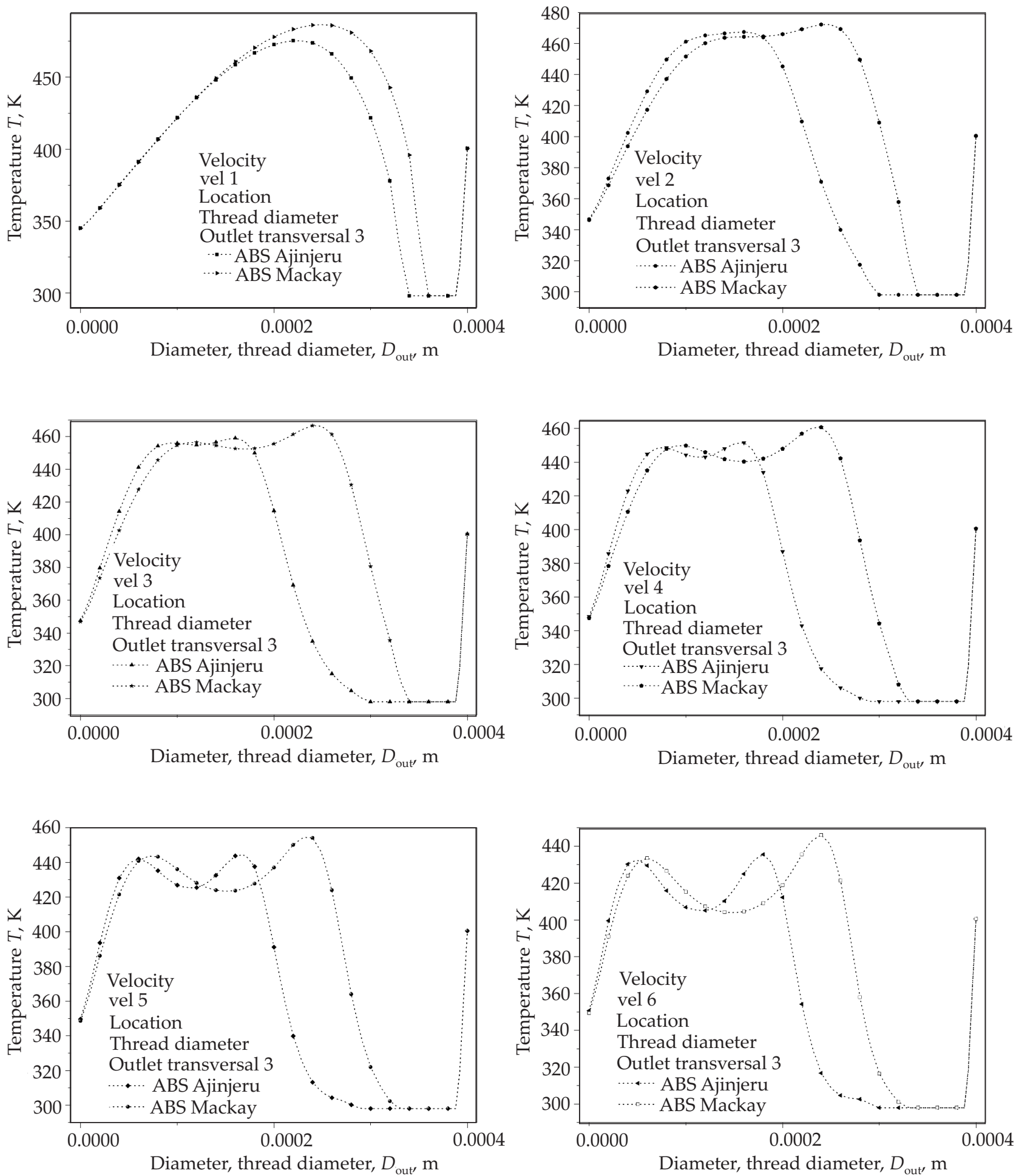

Fig. 12. Temperature of the nozzle tip, at the entrance and outlet

viscosity decreases linearly (power law model) and there is reason why the curves decreases gradually. When the vortices increases the temperature decreases. The same situation occurs with the polymer used by Mackay [21].

The temperature at the outlet 1 can be seen in Fig. 10 at the beginning there is small difference between the temperatures of the polymers, this happens because the viscosity is different between them, however, when the velocity increases considerably can be observed that no difference is present between the material, this might happen because the rheological values is no longer relevant at this velocities but mainly the location where the curve was obtained.

Figure 11 corroborates the behavior in the temperature for both polymers previously explained from Fig. 7 and Fig. 8. The viscosity have an strong influence that is the reason why the material from Ajinjeru's present higher temperatures than Mackay's from 0 to $0.0002 \mathrm{~m}$ diameter, 


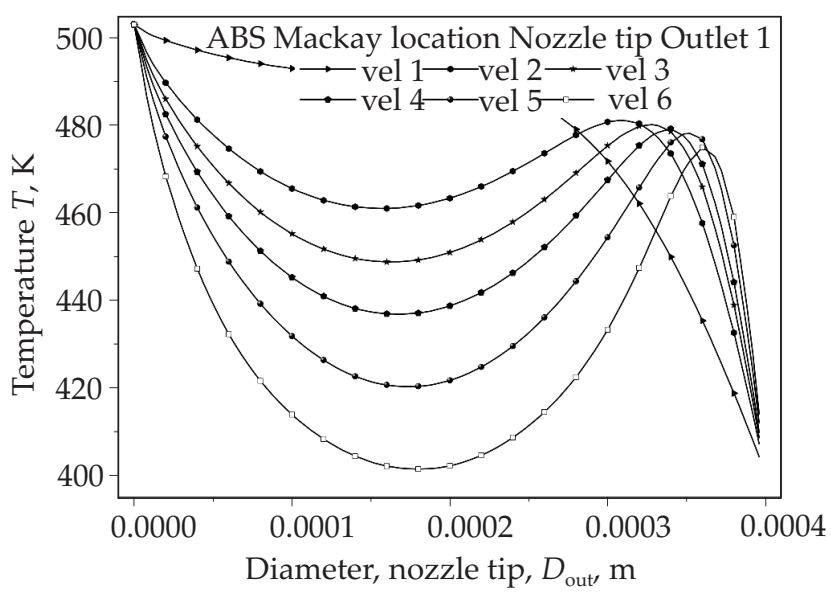

Fig. 13. Temperature at the outlet 1; ABS Mackay

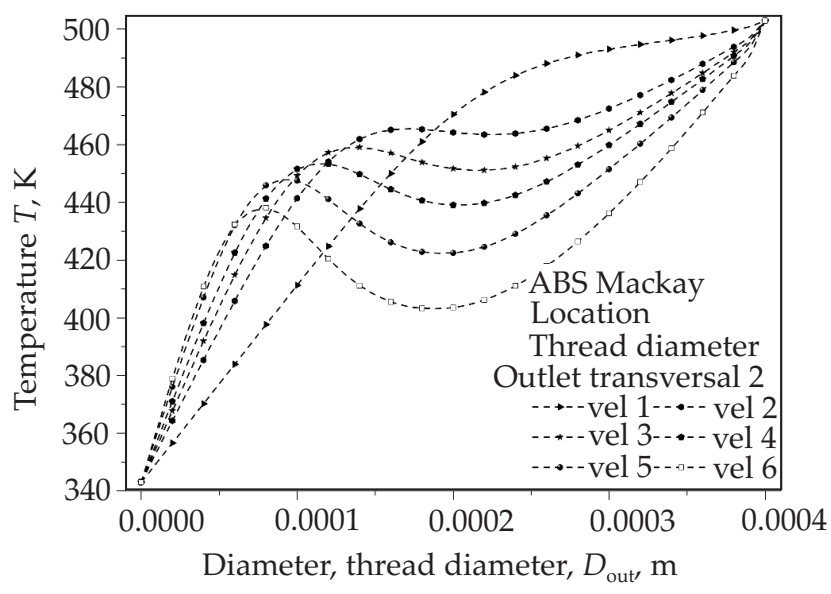

Fig. 14. Temperature at the outlet transversal 2; ABS Mackay

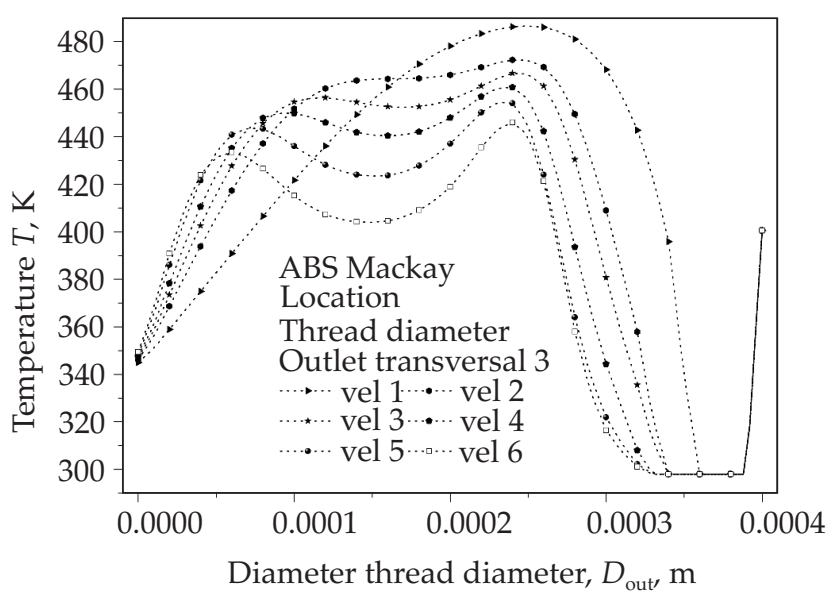

Fig. 15. Temperature at the outlet transversal 3; ABS Mackay

because the temperature from the transversal wall of the nozzle still having influence in the viscosity of the material. Such temperatures are obtained before the material is shared by the wall of the nozzle (outlet transversal 2).

When the temperature is measured after the material suffered shearing process the temperature increases considerably but must be consider that material proposed by Mackay's now have higher temperatures than Ajinjeru's. Therefore, this might be caused by the rheological properties of the material that is more susceptible to veloc- ity changes and shearing changes. This can be seen in Fig. 12. Figures 13, 14 and 15 represent the same behavior as previously explained before using the ABS from Ainjeru. Between the behavior presented using ABS from Ajinjeru and the behavior using ABS from Mackay a correlation with the viscosity exist, as was explained before.

\section{CONCLUSIONS}

Was observed that viscosity changes of two different ABS polymer grades result in temperature changes and presence of vortices when the system uses different printing velocities. Lowering the viscosity might be beneficial while the material does not suffer any shear, because the temperature stills higher. However, when the material presents a shear effect a polymer with higher viscosities are needed because the vortices are lowered, and the temperature might least longer when the thread is subjected to environment temperature. Hence, with this idea we can reach a principal point of view:

- The use of the first velocity melts the material entirely, but the printing time goes up drastically till the moment that one single product might take up to days.

- The use of velocity 2 to 4 in both polymers are quite relevant the vortices present low changes after velocity 4 the same goes for the temperature.

- Which material is more suitable for printing? The answer is both because one presents better temperatures and the other one presents less vortices. However, a strict decision, everything leads us to ABS from Mackay's because the vortices are lowered, and the probability of lowering the degradation behavior increases.

Was observed that shearing analysis from the wall of the nozzle to the printing bed have great influence on the printed thread, temperature increases considerably but also velocity changes are present along with vortices and with higher probabilities of stagnation point. When, the velocity increases the vortices increases as well, because there is a coalition of velocities (printing velocities and feeding velocity), such behavior is connected by the viscosity of the materials.

Changing the ABS grades have a great impact in the temperatures as was shown in the previous graphs. Before shearing the material from the nozzle wall against the bed, the temperatures play better in Ajinjeru's polymer while Mackay's shows lower temperature response. However, when the materials are sheared the scenario goes in the other way around, meaning that viscosity plays an important role.

\section{REFERENCES}

[1] Huang B., Singamneni S.: Proceedings of the Institution of Mechanical Engineers, Part B: Journal of Engineering Manufacture 2014, 228 (1), 111. http://dx.doi.org/10.1177/0954405413497474 
[2] Guo N., Leu M.C.: Frontiers of Mechanical Engineering 2013, 8 (3), 215. http://dx.doi.org/10.1007/s11465-013-0248-8

[3] Turner B.N., Gold S.A.: Rapid Prototyping Journal 2015, 21 (3), 250.

http://dx.doi.org/10.1108/RPJ-02-2013-0017

[4] Turner B.N., Strong R., Gold S.A.: Rapid Prototyping Journal 2014, 20 (3), 192.

http://dx.doi.org/10.1108/RPJ-01-2013-0012

[5] Thrimurthulu K., Pandey P.M., Reddy N.V.: International Journal of Machine Tools and Manufacture 2004, 44 (6), 585. http://dx.doi.org/10.1016/j.ijmachtools.2003.12.004

[6] Kulkarni P., Dutta D.: Journal of Manufacturing Science and Engineering 1999, 121 (1), 93. http://dx.doi.org/10.1115/1.2830582

[7] Alexander A., Allen S., Dutta D.: Computer-Aided Design 1998, 30 (5), 343. http://dx.doi.org/10.1016/S0010-4485(97)00083-3

[8] Kolossov S., Boillat E., Glardon R. et al.: International Journal of Machinery Tools Manufacturing 2004, 44 (2), 117. http://dx.doi.org/10.1016/j.ijmachtools.2003.10.019

[9] Fodran E., Koch M., Menon U.: "Mechanical and Dimensional Characteristics of Fused Deposition Modelling Build Styles", International Solid Freeform Fabrication Symposium 1996. http://dx.doi.org/10.15781/T20V8B325

[10] Bertoldi M., Yardimci M., Pistor C.M. et al.: "Mechanical Characterization of Parts Processed via Fused Deposition", International Solid Freeform Fabrication Symposium 1998. http://dx.doi.org/10.26153/tsw/646

[11] Gurrala P.K., Regalla S.P.: Virtual and Physical Prototyping 2014, 9 (3), 141. http://dx.doi.org/10.1080/17452759.2014.913400

[12] Zhou Y., Nyberg T., Xiong G., Liu D.: “Temperature Analysis in the Fused Deposition Modeling Process", 2016 3rd International Conference on Information Science and Control Engineering (ICISCE), July 2016, pp. 678-682. http://dx.doi.org/10.1109/ICISCE.2016.150

[13] Yardimci M.A., Hattori T., Guceri S.I., Danforth S.C.: "Thermal Analysis of Fused Deposition", 1997
International Solid Freeform Fabrication Symposium, University of Texas, Austin 1997, vol. 8, p. 10.

[14] Wang Z., Smith D.E.: Journal of Composites Science 2018, 2 (1), 10. http://dx.doi.org/10.3390/jcs2010010

[15] Ramanath H.S., Chua C.K., Leong K.F., Shah K.D.: Journal of Materials Science: Materials in Medicine 2008, 19 (7), 2541. http://dx.doi.org/10.1007/s10856-007-3203-6

[16] Nikzad M., Sayed H.M., Sbarski I., Groth A.: Tsinghua Science and Technology 2009, 14 (S1), 29. http://dx.doi.org/10.1016/S1007-0214(09)70063-X

[17] Papon E.A., Haque A., Sharif M.: "Effect of Nozzle Geometry on Melt Flow Simulation and Structural Property of Thermoplastic Nanocomposites in Fused Deposition Modeling", Proceedings of The American Society for Composites, Thirty-Second Technical Conference October 2017. http://dx.doi.org/10.12783/asc2017/15339

[18] Heij W.J.: "Feed velocity feedback for high speed fused deposition modelling machines", Master thesis, Biomedical Engineering, TU Delft, TU Delft Netherlands 2016.

[19] Bellini A.: "Fused deposition of ceramics: a comprehensive experimental, analytical and computational study of material behavior, fabrication process and equipment design liDEA: DREXEL LIBRARIES E-REPOSITORY AND ARCHIVES", Ph.D., Engineering, Materials Science, Drexel University 2002.

[20] Ajinjeru C., Kishore V., Chen X. et al.: “The Influence of Rheology on Melt Processing Conditions of Amorphous Thermoplastics for Big Area Additive Manufacturing (BAAM)", Proceedings of the 27th Annual International Solid Freeform Fabrication Symposium, August 2016.

[21] Mackay M.E., Swain Z.R., Banbury C.R. et al.: Journal of Rheology 2017, 61 (2), 229. http://dx.doi.org/10.1122/1.4973852

[22] Geng P., Zhao J., Wu W. et al.: Journal of Manufacturing Processes 2019, 37, 266. http://dx.doi.org/10.1016/j.jmapro.2018.11.023

Received 20 VIII 2020.

\section{(3) Polimery - czasopismo naukowo-techniczne \\ Plik É Edycja Widok Historia Zzakładki Narzędzia Ponoc

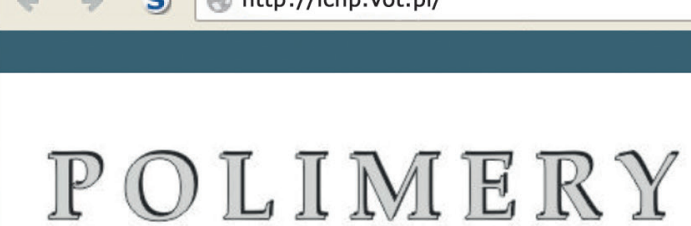

